\title{
Nauczanie zdalne - wyzwanie dla edukacji nie tylko w czasie pandemii
}

\section{Remote learning - a challenge for education not only in the time of a pandemic}

\author{
Anna Sałatarow \\ Uniwersytet Jagielloński, Kraków \\ ORCID: 0000-0001-5986-0900
}

\begin{abstract}
This article pays attention to solutions connected with remote tutorship, which were developed before the epidemiological crisis and before the coercion of implementation remote forms of teaching. The research of diverse methods of remote teaching was done, including such forms as webinars, interactive tasks and tests. The article is also pointing some advantages and disadvantages of remote education. Also the questionnaire in group of students was done in order to check out what methods are perceived as the most and the less attractive.
\end{abstract}

Key words: educational platform, remote tutorship, online lessons, webinars

Streszczenie: Niniejszy artykuł zwraca uwagę na rozwiązania w zakresie nauczania zdalnego, które zostały wypracowane jeszcze przed tym, gdy świat musiał zacząć mierzyć się z kryzysem epidemiologicznym i rozpocząć wdrażanie form pracy odpowiadających na potrzeby nowej rzeczywistości. Dokonany został przegląd rozmaitych form zdalnej pracy z uczniami, między innymi webinarów, indywidualnych wideospotkań oraz interaktywnych zadań i testów, a także pokrótce omówiony ich potencjał. Aby zweryfikować to, jakie narzędzia są postrzegane przez odbiorców za najbardziej efektywne oraz które są dla nich najatrakcyjniejsze, przeprowadzona została internetowa ankieta wśród grupy studentów korzystających z różnych form nauczania zdalnego.

Słowa kluczowe: platforma edukacyjna, nauczanie zdalne, lekcje online, webinary

W dobie pandemii sytuacja szkolnictwa uległa drastycznym zmianom, szczególnie w związku z koniecznością stosowania metod nauczania zdalnego. Dla wielu uczniów i nauczycieli mogło to stanowić nowość, a jednocześnie duże wyzwanie. Należy jednak zauważyć, że rozmaite formy edukacji zdalnej towarzyszyły procesowi edukacji na różnych etapach już od wielu lat, a ich rozwój postępował wraz z poszerzaniem dostępności do Internetu i nowych technologii oraz sprzętów - od komputerów do urządzeń mobilnych. Choć dla wielu pojęcie kształcenia zdalnego może wydawać się wytworem naszych czasów, to warto nadmienić, że początki edukacji na 
odległość sięgają znacznie dalej. Na świecie pierwsze szkoły i uniwersytety korespondencyjne pojawiały się już w XIX wieku, a głównym narzędziem była wówczas poczta. Mimo braku dostępności do zaawansowanych technologii nauka korespondencyjna miała także znaczenie w podtrzymywaniu i odbudowywaniu tożsamości narodowej - w Polsce szczególnie w historycznie trudnych okresach.

Analiza narzędzi i rozwiązań, sprawdzonych już w zakresie edukacji zdalnej, może okazać się istotnym wsparciem dla nauczycieli i edukatorów, którzy w obliczu pandemii zostali nakłonieni do wdrażania innych form nauczania niż tradycyjne lekcje w klasie. Dlatego rozpoczynając rozważania dotyczące edukacji online, warto zwrócić uwagę na znaczenie form nauczania zdalnego w trybie edukacji domowej, która funkcjonuje już od lat ${ }^{1}$ i z roku na rok zyskuje coraz większą popularność w Polsce. Rodzice, decydujący się edukować swoje dziecko $\mathrm{w}$ domu, często potrzebują wsparcia $\mathrm{w}$ wybranych obszarach nauczania. Z myślą o nich powstały platformy edukacyjne przeznaczone dla dzieci i nastolatków realizujących polską podstawę programową bez konieczności uczestniczenia w stacjonarnych zajęciach szkolnych. Takie platformy edukacyjne funkcjonują już od kilku lat na polskim rynku i aktualnie prowadzone są m.in. przez Centrum Nauczania Domowego czy Polską Szkołę Internetową Alfa i Omega.

Doświadczenie zawodowe zdobyte przeze mnie w Polonijnym Zespole Placówek Oświatowych, czyli miejscu zajmującym się internetową edukacją dzieci objętych nauczaniem domowym w Polsce oraz dającym możliwość realizowania treści z zakresu polskiej podstawy programowej w dowolnym miejscu na świecie, wskazuje, że co najmniej od kilku lat istnieje zapotrzebowanie na usługi edukacyjne w tym zakresie. Osoby zapisujące dzieci do projektów edukacyjnych oferujących kształcenie zdalne niejednokrotnie wskazywały na liczne zalety takiego rozwiązania (np. możliwość dostosowania ścieżki rozwoju i doboru zadań do indywidualnych potrzeb ucznia, swobodę w ustalaniu czasu i tempa jego pracy, budowanie pozytywnych nawyków dotyczących organizacji miejsca i czasu nauki, atrakcyjność zadań interaktywnych).

Zatem warto mieć na uwadze, że jeszcze przed nastaniem wiosną 2020 roku nowych realiów i reżimu sanitarnego związanego z rozwojem epidemii wiele osób decydowało się na korzystanie z metod zdalnej nauki, nie tylko $\mathrm{w}$ tak szerokim zakresie, jak realizowanie podstawy programowej w domu, ale również na przykład do kształcenia w konkretnej dziedzinie nauki.

Obserwując ofertę tego typu platform edukacyjnych, można zauważyć, że szczególnie często wykorzystywane są formy takie, jak: udostępnianie materiałów edukacyjnych ( $\mathrm{w}$ tym zadań interaktywnych i testów sprawdzających wiedzę) pozwalających na samodzielną pracę ucznia bądź pracę z pomocą rodzica, grupowe lekcje online (w postaci wykładu, bez

${ }^{1}$ Zgodnie z prawem oświatowym od 1991 roku jest jednym z pełnoprawnych sposobów realizowania obowiązku szkolnego w Polsce. 
możliwości zabrania głosu, lub w formie angażującej uczniów poprzez ich odpowiadanie na zadane pytania, udział w dyskusji), indywidualne lekcje z nauczycielem bądź korepetytorem. Każda z wymienionych form cechuje się dowolnością miejsca nauki, a czasem także możliwością swobodnego dostosowania czasu nauki do własnych potrzeb, co oznacza dużą elastyczność i może być postrzegane jako niezwykle cenne ${ }^{2}$. Te cechy istotnie wpływały na wybór zdalnych form nauczania jeszcze przed pandemią - zarówno w ramach korepetycji, jak i różnego rodzaju kursów.

Inną zaletą nauczania zdalnego jest możliwość wykorzystania zadań interaktywnych, filmów, grafik, animacji, czyli takich form urozmaicenia materiału edukacyjnego, które często ze względów technicznych są trudne do wprowadzenia na tradycyjnej lekcji. W przypadku lekcji prowadzonej na żywo, w formie wideo, możliwość jednoczesnego wyświetlania prezentacji multimedialnej może nie tylko wzbogacać wykład o ciekawe i przyciągające uwagę elementy, ale także pozwala na usystematyzowanie treści nauczania. $\mathrm{Z}$ tego powodu prezentacja multimedialna może stanowić wsparcie, dzięki któremu realizacja treści w ciągu danej jednostki lekcyjnej może przebiegać zgodnie z uprzednio przygotowanym planem. Dobrze przygotowana prezentacja, spójna z wypowiedzią i uzupełnieniami ze strony nauczyciela, wpłynie również pozytywnie na procesy zapamiętywania przez uczniów oraz zwiększy prawdopodobieństwo, że przekazywane informacje dotrą do odbiorców (w przypadku angażowania tylko jednego kanału odbioru większe jest prawdopodobieństwo, że część osób nie usłyszy lub źle usłyszy dany przekaz) - polisensoryczne podejście stosowane w nauczaniu niesie za sobą te i inne korzyści, przez co warto zwracać uwagę na wykorzystanie różnego typu materiałów w pracy z uczniami (Włodarski 1979).

Elementy gier, animacji, które nauczyciel jest w stanie wprowadzać do swoich lekcji online, mogą także przyczynić się do pogłębiania zaangażowania uczniów i motywowania ich do aktywnego udziału w zajęciach. Jedną z ciekawych propozycji wykorzystania opcji udostępniania pulpitu podczas spotkań za pośrednictwem MS Teams jest przygotowanie „koła fortuny” (Grochowska, Krenc, Przybysz 2020). Autorki wzbudzały motywację dzieci, przekształcając tradycyjne odpytywanie w emocjonującą rozgrywkę. Warto zaznaczyć, że dzięki dostępnym technologiom przygotowanie takiego narzędzia nie powinno zająć wiele czasu, jest to stosunkowo nieskomplikowane, a raz przygotowany mechanizm z łatwością można dostosować do dowolnego tematu jedynie poprzez zmianę zamieszczonych pytań. Rozmaite formy nauki online pozwalają więc na zróżnicowanie materiałów (w tym wykorzystanie tych interaktywnych) oraz stosowanie zaskakujących metod i narzędzi pracy, a więc stwarzanie sytuacji angażujących emocjonalnie

${ }^{2}$ Co prawda, tradycyjny tryb nauki w szkole, nawet w systemie hybrydowym lub zdalnym, nie jest tak elastyczny jak edukacja domowa, niemniej jako pewną dogodność można nadal postrzegać dowolność miejsca, w którym można lekcję przeprowadzić lub w niej uczestniczyć (w przypadku zajęć online). 
odbiorców, co - jak dowodzi Zbigniew Meger (2008) - bezpośrednio oddziałuje na efekty nauki.

Również w zakresie nauki języków obcych rozmaite formy nauki zdalnej od lat stanowią wsparcie lub są alternatywnym rozwiązaniem. Podkreśla się rolę edukacyjnych zasobów online dla wczesnej edukacji językowej, polegającą np. na wykorzystywaniu bajek w języku obcym (np. poprzez serwis YouTube), odtwarzaniu piosenek, wykorzystaniu ćwiczeń interaktywnych (Basińska 2017, 37-38). Rozwój Internetu i coraz sprawniejsze funkcjonowanie różnego rodzaju komunikatorów powoduje, że języki obce można doskonalić przez bezpośredni kontakt z tzw. native speakerami, chociaż nauka języków obcych metodami zdalnymi była możliwa już wcześniej - między innymi za pośrednictwem programów telewizyjnych. Językowa edukacja zdalna wykorzystuje w zasadzie wszelkie dostępne formy - od materiałów przesyłanych przez e-mail, przez platformy zawierające filmy instruktażowe do odsłuchu, aż po bezpośrednie spotkania wideo z nauczycielem $^{3}$. Dzięki szerokiemu wykorzystaniu technik pracy na odległość poszerzyły się możliwości nauki języków obcych, a wiedzę można zdobywać niemal zawsze i wszędzie, nawet bez konieczności posiadania stałego połączenia internetowego, tak jak w przypadku aplikacji Duolingo, która oferuje naukę zarówno w trybie online, jak i offline ${ }^{4}$. Wymieniona powyżej aplikacja nie jest jedyną tego rodzaju, wystarczy wspomnieć np. Memrise, Quizlet czy Supermemo.

Należy jednak zaznaczyć, że wszystkie formy zdalnej nauki niosą ze sobą pewne ograniczenia. Sceptyczne podejście do edukacji na odległość wynikać może z zastrzeżeń co do tego, że nie sprzyja ona rozwojowi umiejętności nabywanych przez uczniów w bezpośrednim kontakcie z innym człowiekiem - nauczycielem, ale też grupą rówieśniczą. Inną kwestią jest to, że wymagają dostępu do rozmaitych urządzeń - w zależności od formy nauki może to być komputer, tablet, smartfon, mikrofon, słuchawki, kamera umożliwiająca połączenie wideo. Szczególnie w sytuacji, kiedy pewien rodzaj nauki zostaje niejako narzucony, ponieważ musi zastąpić tradycyjne zajęcia w szkole, dostęp ten może być problematyczny. Dodatkowo, wiele form nauki zdalnej wymaga stałego i dobrej jakości łącza internetowego. Niejednokrotnie także warunki lokalowe stanowią utrudnienie w realizacji tak spełnianego obowiązku szkolnego (na przykład w sytuacji braku pomieszczenia, w którym dziecko w ciszy i skupieniu mogłoby brać udział w lekcji online).

Trudnością związaną z wprowadzaniem do systemu oświaty nauczania zdalnego jest również to, że nie każde dziecko, zwłaszcza najmłodsze, potrafi samodzielnie z takich narzędzi korzystać, a uzyskanie wsparcia od

\footnotetext{
${ }^{3}$ Wspomnieć można np. platformę Moodle, z której korzystać mogą także nauczyciele chcący tworzyć i zamieszczać tworzone przez siebie materiały cyfrowe; platformą do nauki języków obcych jest np. e-tutor.pl, a np. Preply oferuje dostęp do korepetytorów także z innych dziedzin nauki.

${ }^{4}$ Co ciekawe, platforma ta dostępna jest również w wersji dla szkolnych klas, przez co nauczyciele mogą wzbogacać swoje lekcje.
} 
rodzica bądź innego opiekuna nie zawsze jest możliwe. Także kwestia dyscypliny w przypadku grupowych zajęć online stanowi nie lada wyzwanie nawet dla doświadczonego nauczyciela. Podczas lekcji wideo dysponuje on zupełnie innymi środkami oddziaływania na uczniów niż w przypadku tradycyjnej szkolnej lekcji. Nie ma możliwości bezpośredniego przeniesienia zasad panujących w klasie do nowej rzeczywistości, nie wszystkie zakazy i nakazy będą potrzebne w sytuacji, w której uczeń przebywa w domu. $\mathrm{Z}$ tego powodu nauczyciele i edukatorzy prowadzący zajęcia $\mathrm{w}$ formie zdalnej powinni dokładnie przemyśleć kwestie organizacyjne - zadać sobie pytanie o to, jakie zasady powinny panować na zajęciach zdalnych, w jaki sposób je wprowadzać i egzekwować, a także jakie strategie oddziaływania na uczniów warto wykorzystać. Wymaga to dokładnego zweryfikowania swoich oczekiwań i wyobrażeń na temat współpracy z podopiecznymi. Jednym z pomysłów na wprowadzenie określonych zasad podczas lekcji zdalnych jest ustalenie nowego regulaminu (nazywanego też kodeksem lub kontraktem klasowym), dostosowanego do zmienionych warunków. Warto zapoznać uczniów z zasadami netykiety, określić terminy i sposoby oddawania zadań oraz jasno określić swoje oczekiwania co do aktywności uczniów podczas lekcji (Wedeł-Domaradzka, Raczyńska 2013, 35-45).

Niezwykle istotną kwestią jest przeanalizowanie możliwych do wdrożenia strategii angażowania uczniów w przeprowadzane zajęcia online. Największą liczbą narzędzi dysponuje pod tym względem tutor/nauczyciel wykorzystujący wideorozmowy, a jego komunikacja z odbiorcą jest bezpośrednia i synchroniczna. Należy jednak pamiętać także o atrakcyjności przekazu, zwłaszcza jeśli lekcja odbywa się w formie webinaru, w którym komunikacja między prowadzącym a uczestnikami nie jest synchroniczna, lub prowadzony jest wykład dostępny dla odbiorców jedynie w formie nagrania. Metody podające, chociaż pozwalają na przekazanie bardzo dużej liczby informacji, są wymagające pod względem odpowiedniego zastosowania. Podstawowe kwestie, o które należy zadbać, przystępując do przygotowania i przeprowadzenia takich zajęć, to m.in.:

- uporządkowanie widzianego przez odbiorców otoczenia. Często zdarza się, że lekcje online przeprowadzane są przez nauczycieli, wykładowców, tutorów w warunkach domowych, z czego zdają sobie sprawę również odbiorcy. Jednak tło, na którym znajduje się osoba prowadząca zajęcia, może być rozpraszające lub wręcz zmniejszające atrakcyjność odbioru. Idąc śladem profesjonalnych firm, zajmujących się edukacją za pośrednictwem Internetu, warto wybrać jedno miejsce, które nie tylko będzie dogodne dla prowadzącego, ale też będzie wyglądało schludnie. Zbyt duża liczba widocznych przedmiotów, rozpraszający natłok kolorów czy bałagan znacząco obniża jakość odbioru wystąpienia. Dlatego warto zadbać o porządek, stonowaną kolorystykę, odpowiedni poziom 
oświetlenia, a przedmioty, które będą widziane, można dobrać tak, by na przykład nawiązywały do poruszanego tematu bądź były po prostu neutralne;

- odpowiednie ustawienie i dobra jakość wykorzystywanego sprzętu. Oczywistą kwestią jest to, że szumy, przerywanie ciągłości dźwięku, niewyraźny obraz nie sprzyjają atrakcyjności czy nawet czytelności komunikatu. Przed przystąpieniem do zajęć warto przeprowadzić próbę obrazu i dźwięku oraz sprawdzić ustawienie kadru, ponieważ postać znajdująca się zbyt blisko lub zbyt daleko kamery niekorzystnie wpływa na koncentrację odbiorców;

- dbałość o modulację głosu i odpowiednią jego głośność, utrzymującą uwagę odbiorcy intonację, a także poprawność i wyraźność wypowiedzi. Dzięki szczególnej uwadze poświęconej tym elementom zwiększa się poziom zaangażowania i skupienia odbiorców, nawet jeśli zajęcia prowadzone są jedynie $\mathrm{w}$ formie nagrania do późniejszego odsłuchu.

Obecnie istnieje wiele narzędzi umożliwiających komunikację wideo między pojedynczymi osobami lub dających możliwość tworzenia wideokonferencji. Do popularnych oprogramowań wykorzystywanych w celu przeprowadzania lekcji online $\mathrm{w}$ formie wideospotkań należą $\mathrm{m}$. in. Microsoft Teams, Zoom, Cisco Webex Meetings, ale w przypadku zajęć indywidualnych korzysta się także z programów typu Skype. Spośród platform komunikacyjnych przydatnych do organizowania lekcji online warto również wymienić ClickMeeting - polską platformę do webinarów. Daje ona możliwość spotkań indywidualnych, grupowych, a także wykorzystania wirtualnej tablicy oraz czatu. Wśród podobnych platform polskiego użytkownika zainteresować może MyOwnConference oraz Skype for Business (dostępną w języku polskim).

Techniczne aspekty dostępnych oprogramowań, ich dobór do konkretnych potrzeb danego nauczyciela i ucznia oraz sposób przygotowania lekcji dostosowanej do wybranej aplikacji to zagadnienia, którym z pewnością warto poświęcić odrębne opracowania. Aby zbadać, jakie narzędzia są postrzegane przez odbiorców za najbardziej efektywne oraz które są dla nich najatrakcyjniejsze, a także z jakimi metodami studenci spotykają się najczęściej, czyli jakie rozwiązania cieszą się obecnie największą popularnością, przygotowałam ankietę. Grupę badawczą stanowiło 39 studentów (100\% badanych) różnych lat i kierunków, korzystających w trakcie swojej edukacji z metod zdalnego kształcenia. Wśród ankietowanych miały szansę znaleźć się osoby kształtujące swoje opinie na podstawie doświadczeń z edukacją zdalną na różnych etapach kształcenia, a co wynika z wieku - także w czasach sprzed pandemii. W ciągu kilku lat zmieniał się też repertuar najczęściej stosowanych narzędzi, dlatego ogląd z perspektywy pozwala na uwzględnienie także tych rozwiązań, które dziś już mogły stracić na popularności. 
Analiza internetowej ankiety dotyczącej form nauczania zdalnego, przeprowadzonej w 2020 roku, wskazuje, że największa liczba badanych (89,7\% - 35 osób) miała kontakt z nauczaniem zdalnym na etapie studiów wyższych, mniejsza liczba (33,3\% - 13 osób) na etapie szkoły średniej, a najmniejsza (12,8\% - 5 osób) na poziomie szkoły podstawowej lub gimnazjum. Na to pytanie można było udzielić więcej niż jednej odpowiedzi, co oznacza, że były osoby korzystające ze zdalnych form nauki na więcej niż jednym etapie swojej edukacji. Wpływ na taki rozkład odpowiedzi mogło mieć kilka czynników - między innymi to, że w najbliższej dla ankietowanych przeszłości, czyli w czasie studiów wyższych, była stosunkowo największa dostępność narzędzi do nauczania zdalnego i takie formy były już w pewien sposób rozpowszechnione.

Ankietowani zostali następnie zapytani, z jakimi formami nauki zdalnej mieli styczność w trakcie swojej edukacji. W formularzu istniała możliwość zaznaczenia wszystkich wymienionych form nauczania, a rozkład odpowiedzi był następujący:

- $\quad$ wykład/lekcja online (na żywo): 84,6\% (33 osoby);

- wykład/lekcja online (w formie nagrania do odtworzenia): $74,4 \%$ (29 osób);

- indywidualne zajęcia w formie wideospotkania: 41\% (16 osób);

- internetowa platforma edukacyjna: 48,7\% (19 osób);

- korzystanie z materiałów edukacyjnych zamieszczonych w sieci (w tym ćwiczeń interaktywnych): 92,3\% (36 osób);

- programy telewizyjne i radiowe: 15,4\% (6 osób);

- konsultacje telefoniczne: 17,9\% (7 osób)5

W dalszej części ankiety badani zostali zapytani o to, które z form nauki online uważają za najbardziej efektywne i dlaczego. Nie wszyscy ankietowani udzielili odpowiedzi na to pytanie (pojawiły się 34 odpowiedzi), a cztery osoby wskazały, że żadna forma nauczania zdalnego nie jest ich zdaniem efektywna ${ }^{6}$. Najczęściej wskazywaną był natomiast wykład/lekcja online (na żywo) - tak odpowiedziało 16 osób, a uzasadnieniem najczęściej było to, że jest ona zbliżona do tradycyjnych zajęć ${ }^{7}$. Ankietowani podkreślali fakt możliwości zadania pytania i uzyskania natychmiastowej odpowiedzi oraz kwestię bezpośredniego kontaktu z innymi uczestnikami, nadto - że jest to forma angażująca.

Na pytanie o najmniej efektywne formy nauki online odpowiedziało 32 respondentów. Wśród wskazanych w tym miejscu dominowały wykłady do

\footnotetext{
${ }^{5}$ Jedna osoba $(2,6 \%)$ skorzystała z możliwości dodania innej odpowiedzi i wskazała na aplikację mobilną do nauki języka obcego.

6 Trzy osoby nie uzasadniły swojego stanowiska, natomiast jedna stwierdziła, że żadna ze zdalnych form nauczania nie jest efektywna, ponieważ nie jest w stanie zastąpić tradycyjnych zajęć.

7 Przykładowe odpowiedzi ankietowanych to: „Lekcja online, ponieważ jest najbardziej podobna do tradycyjnych zajęć”, „Wykłady online, które dają namiastkę normalności”, „Zajęcia online na żywo, ponieważ taka forma najbardziej przypomina zajęcia stacjonarne”. Na tej podstawie zauważyć można, że podobieństwo do tradycyjnie prowadzonych zajęć uznawane jest za wartość, a także, że stacjonarne nauczanie jest zdaniem badanych wzorem dla nowoczesnych form edukacji.
} 
odtwarzania (10 odpowiedzi) oraz materiały edukacyjne do samodzielnej pracy (8 odpowiedzi). Badani uzasadniali swoje odpowiedzi najczęściej tym, że w wymienionych formach brakuje im bezpośredniego kontaktu z prowadzącymi, a bez wystarczających instrukcji i wyjaśnień czują się zagubieni wśród przesyłanych materiałów, brakuje im także motywacji do korzystania z materiałów i nagrań (pojawiają się trudności z odpowiednią organizacją czasu poświęconego na samodzielną pracę, a brak elementów interakcji sprawia, że zajęcia są monotonne) $)^{8}$.

Warto zwrócić uwagę, że pojawiły się cztery odpowiedzi stwierdzające, że żadna metoda zdalna nie jest efektywna. Oto jedna z nich: „Uważam, że zdalne nauczanie jako ekwiwalent tradycyjnego nauczania zupełnie się nie sprawdza i jest największą porażką w dziejach edukacji. Nic nie może zastąpić tradycyjnych zajęć. Taka forma jest monotonna, nie sprzyja przyswajaniu wiedzy, a informacje, które zostały w ten sposób przyswojone, szybko ulegają zapomnieniu". Pokrywa się to ze stwierdzeniami widocznymi w odpowiedziach na poprzednie pytanie, co może świadczyć o jednoznacznie negatywnych doświadczeniach z edukacją zdalną i wskazuje na wyraźne preferowanie stacjonarnej formy zajęć. Niechęć uczniów do przyjętych nowych sposobów prowadzenia lekcji w czasie pandemii wykazało także zakrojone na większą skalę badanie jakościowe (Ptaszek, Stunża, Pyżalski, Dębski, Bigaj 2020), a ankietowana młodzież szkolna zwracała uwagę na brak odpowiednich wyjaśnień treści edukacyjnych, zbyt dużą ich ilość, ale także na nieumiejętne wykorzystanie narzędzi z zakresu nowych technologii. Zaobserwować można analogie pomiędzy wynikami niezależnych od siebie badań, co pokazuje, że trudności i wyzwania stojące przed uczniami i edukatorami w sytuacji epidemii są uniwersalne.

W trakcie przeprowadzonego przeze mnie mikrobadania, ankietowani zostali zapytani także o to, czy w trakcie swojej edukacji brali udział w sprawdzianie/egzaminie online. Zdecydowana większość - 84,6\% (33 osoby) odpowiedziała twierdząco. Kolejnym pytaniem było to, w jakiej formie (ustnej czy pisemnej) był on przeprowadzany. Wyniki rozłożyły się następująco: $60,6 \%$ osób brało udział w egzaminach w formie ustnej, natomiast w formie pisemnej - 39,4\%. Na tej podstawie wywnioskować można, że zdalne sprawdzanie wiedzy jest już dość rozpowszechnioną praktyką, a forma ustna cieszy się większą popularnością i - jak widać w odpowiedziach na następne pytanie - również przez uczących się jest ona preferowana.

Kolejne, przedostatnie już pytanie brzmiało: „Czy uważasz, że zdalne formy egzaminowania/sprawdzania wiedzy są skuteczne? Uzasadnij swoje stanowisko". Ponad połowa osób wskazała, że takie formy egzaminowania nie są skuteczne. Wśród uzasadnień takiego stanowiska najczęściej pojawiały się głosy, że zdalne formy egzaminowania stwarzają większe

\footnotetext{
${ }^{8}$ Przykładowe odpowiedzi to: „Przysyłanie materiałów poprzez e-mail lub inną drogą (w szczególności, jeśli jest zbiorcze). Brak odczuwalnego kontaktu z prowadzącym, trudno jest wygospodarować sobie czas oraz zmotywować się do pracy”, „Nagrane wykłady. Brak bezpośredniego kontaktu, problemy z jakością, nie ma możliwości zadawania pytań na bieżąco".
} 
prawdopodobieństwo oszukiwania oraz że w czasie egzaminów online często pojawiają się czynniki rozpraszające, np. problemy z łączem internetowym $^{9}$. Pięć odpowiedzi było ambiwalentnych, zwracających uwagę głównie na to, w jaki sposób jest zorganizowany i przeprowadzony egzamin zdalny. Natomiast jedenaścioro respondentów stwierdziło, że zdalne metody egzaminowania są skuteczne, podkreślając, że egzamin online - zwłaszcza ustny za pomocą wideorozmowy - nie różni się zbytnio od tradycyjnej formy, a także że trzeba opanować taki sam zakres materiału, co w przypadku egzaminu stacjonarnego. Nasuwa się więc wniosek, że przygotowanie zdalnych form sprawdzania wiedzy wymaga szczególnej czujności nauczyciela, który powinien zadbać o maksymalną obiektywność egzaminu i zminimalizowanie ryzyka nieuczciwych zachowań. Co więcej, warto zwrócić uwagę na potrzebę przygotowania jasnej instrukcji.

Ostatnie pytanie brzmiało: „Czy uważasz, że wykorzystanie zdalnych form nauczania powinno stać się stałym elementem edukacji szkolnej/studiów wyższych?" W tej kwestii zdania badanych rozłożyły się niemal po równo - 51,3\% (20 osób) odpowiedziało, że tak, a 48,7\% (19 osób), że nie. Trudno jednoznacznie określić powód takiego rozkładu odpowiedzi, natomiast można przypuszczać, że duża liczba odpowiedzi przeczących wynika z negatywnych doświadczeń respondentów - mieli styczność z nieciekawymi prezentacjami, nie dość wyjaśnionymi poleceniami zawartymi w materiałach do samodzielnego wypełnienia, zdarzały im się problemy techniczne albo nie mieli ustalonych jasnych reguł i harmonogramów nauki. Dlatego warto wciąż doskonalić dostępne narzędzia, aby edukacja zdalna mogła stać się ekwiwalentem tradycyjnych rozwiązań.

Analiza ankiety wskazuje, że oczekiwania wobec nauczania zdalnego oscylują wokół podobnych zagadnień, co w przypadku tradycyjnych zajęć - w pewnym stopniu wymagania dotyczące edukacji zdalnej pokrywają się z tymi, które dotyczą rozwiązań stacjonarnych. Wymienić tu można choćby oczekiwanie określenia jasnych reguł pracy, szybkiego reagowania na indywidualne potrzeby uczniów, zapewnienia sprawiedliwych i obiektywnych kryteriów oceny, ustalenia określonego planu działań. Zaznacza się wyraźnie fakt, że odbiorcy od lekcji i egzaminów online oczekują jak największego podobieństwa do stacjonarnych odpowiedników. Zarówno w świetle obserwacji poczynionych na podstawie autorskiej ankiety, jak też badań innych (Ptaszek, Stunża, Pyżalski, Dębski, Bigaj 2020), wyraźna jest potrzeba zwracania szczególnej uwagi na wyczerpujące instrukcje i wyjaśnienia co do zadań i materiałów edukacyjnych wykorzystywanych w kształceniu zdalnym.

Nowy rok szkolny i akademicki 2020/2021 będzie stawiał przed nauczycielami, rodzicami, uczniami oraz studentami wiele wyzwań, ale w obecnej

\footnotetext{
9 Przykładowe odpowiedzi wyglądały następująco: „Nie, ponieważ taka forma sprawdzania wiedzy otwiera wiele możliwości oszukiwania, a także może być niesprawiedliwa, biorąc pod uwagę prawdopodobieństwo wystąpienia problemów technicznych”, „Nie, bo mogą zdarzyć się nieuczciwe zachowania i trudniej to sprawdzić niż na normalnym egzaminie".
} 
sytuacji wydaje się, że również w kolejnych latach trzeba będzie mierzyć się z tego typu trudnościami. Rok nauki w formie hybrydowej lub zdalnej nie pozostanie bez wpływu na kolejny. Zasadne jest więc myślenie o opracowywaniu, doskonaleniu i wdrażaniu nowoczesnych narzędzi służących do edukacji zdalnej. Mimo że dla wielu osób to właśnie nowa rzeczywistość spowodowana pandemią była powodem do zapoznania się z tajnikami nauki online, to warto pamiętać, iż wiele form takiej edukacji funkcjonowało wcześniej. Istnieje zatem już całkiem pokaźny repertuar metod i narzędzi możliwych do wykorzystania. Zmiany, które nastąpiły w edukacji za sprawą klęski epidemiologicznej, mogą więc okazać się szansą na zaznajomienie się z rozmaitymi sposobami nauczania zdalnego oraz na świadome i owocne ich wprowadzanie w szkolną i akademicką rzeczywistość popandemiczną.

\section{Bibliografia}

Basińska Anna, 2017, Język angielski we wczesnej edukacji językowej. Teoria w pigułce, Warszawa, http://www.bc.ore.edu.pl/Content/990/JO 8 1.pdf (dostęp: 10.10.2020).

Grochowska Weronika, Krenc Anna, Przybysz Magdalena, 2020, Nauczanie zdalne - jak powtarzać wiadomości?, w: Kania A., Mucha-Iwaniczko K., Szumal M. (red.), Nauczanie zdalne w dobie pandemii. Wyzwania i doświadczenia edukacji polonistycznej, Kraków, s. 45-49.

Meger Zbigniew, 2008, Czynniki afektywne w zdalnej edukacji, „E-mentor”, nr 25.

Ptaszek Grzegorz, Stunża Grzegorz D., Pyżalski Jacek, Dębski Maciej, Bigaj Magdalena, 2020, Edukacja zdalna: co stało się z uczniami, ich rodzicami i nauczycielami?, Gdańsk, https://zdalnenauczanie.org/wp-content/ uploads/2020/10/ZDALNA-EDUKACJA_FINAL.pdf (dostęp: 11.11.2020).

Wedel-Domaradzka Agnieszka, Raczyńska Anita, 2013, Jak skutecznie prowadzić zajęcia na platformie edukacyjnej? Poradnik, Warszawa.

Włodarski Ziemowit, 1979, Odbiór treści w procesie uczenia się, Warszawa.

\section{O Autorce}

Anna Sałatarow - doktorantka w Szkole Doktorskiej Nauk Humanistycznych UJ w dyscyplinie literaturoznawstwo, absolwentka polonistyki ze specjalnością nauczycielską. Autorka m.in. artykułów w książkach serii „Edukacja nauczycielska polonisty”. Główne obszary zainteresowań to dydaktyka literatury, literatura dokumentu osobistego i związana z tematyką Zagłady. 